\title{
Humor To The Rescue: How To Make Introductory Economics An Appealing Social Science For Non-Majors
}

\author{
George H. Jones, University of Wisconsin - Rock County, USA
}

\begin{abstract}
Despite efforts made over the past few years to improve upon the way introductory economics is taught, these efforts have unfortunately done very little to change student perception of economics as a dry, difficult and boring subject. Since the introductory economics course for many nonmajors may be their only economics course in college, it is incumbent upon those who teach the course to leave a lasting impression of it as a relevant, interesting, and exciting subject to learn. One alternative teaching technique that holds great promise in addressing the negative reputation of economics is humor. Until recently, the use of humor as an alternative teaching technique was shunned and held in disrepute especially in such "dread" courses as economics. Today, the current literature on teaching and learning clearly indicates that the tables have turned and the use of humor as a viable pedagogical approach is on the rise in almost every discipline. The primary goal of this paper is to discuss the vital role of humor as a transformational teaching technique in the introductory economic course. Specifically, the paper discusses the teaching and learning benefits of humor, the appropriate use of humor and some practical suggestions on how economics instructors can incorporate humor into their teaching.
\end{abstract}

Keywords: Humor; Introductory Economics; Non-Majors; Teaching Techniques

\section{INTRODUCTION}

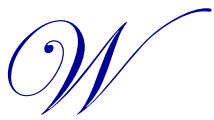

e're beginning to witness, albeit gradually, the rise in the use of alternative techniques to the traditional "chalk-and-talk" method of teaching the introductory economics course. Economics teachers are more eager than before to experiment with such devices as music, movies, stories, and debates to teach their courses (Lawson et al., 2008; Leet \& Houser, 2003; Colander, 2000; Vo \& Morris, 2006). Yet despite these noble attempts to improve upon the way the introductory economics course is taught, they have regrettably done very little to change the negative student perception of economics as a dry, difficult, and boring subject (Armento, 1987; Ray, 1991; Colander, 2000; Deiter, 2000). Unfortunately, this feeling towards economics can adversely undermine student learning and turn potential students from considering economics as a major (Colander, 2000; Deiter, 2000; Ruder, 2010). A careful review of the literature on economic education reveals that the way the subject matter of economics is communicated lacks the "imagination and creativity to turn students on by turning negative perceptions off" (Deiter, 2000, p. 20). One alternative technique that has shown great promise in addressing the negative perception that still haunts economics is humor (Deiter, 2000). Until a few years ago, the use of humor in teaching was shunned and held in disrepute (Bryant, Comisky, \& Zillman, 1979). Today the tables have turned and the use of humor as an effective teaching technique is on the rise in almost every discipline (Berk, 2003; Ulloth, 2003).

The primary goal of this paper is to discuss the vital role humor plays as an effective teaching technique in the introductory economics course for non-majors. To meet this goal, the paper is broken down into four main sections followed by concluding remarks. Section 2 discusses the reasons why the negative perception of economics courses still persists. Section 3 discusses the pedagogical benefits of teaching introductory economics with humor. Section 4 discusses the appropriate uses of humor in the classroom. Section 5 discusses practical steps I have taken 
to incorporate humor in my introductory economics course. The definition of humor used in this paper is the one subscribed to by Robinson (1991) who writes that humor is "any communication which is perceived by any of the interacting parties to be humorous and leads to laughing, smiling or a feeling of amusement" (p. 10).

\section{WHY DO NON-MAJORS STILL PERCEIVE ECONOMICS AS A "DRY" AND "BORING" SUBJECT?}

The lingering perception of economics as a dry and boring subject especially by non-majors can be attributed to three main reasons. First, there is still reluctance on the part of economics instructors to experiment with new and more effective ways of teaching the introductory course. This is evidenced by the passive "chalk-andtalk" method which is still the dominant teaching technique employed in most college economics courses (Becker \& Watts, 1996; Becker \& Watts, 2001; Watts \& Becker, 2008). Second, like their colleagues in the other social sciences, economics teachers have often looked down on the use of learning theory and research even though both could prove beneficial to their teaching. According to Bach and Kelley (1984), the usual attitude of economics teachers towards theories on human learning in such fields as psychology and education "is indifference or a sneering one" (p. 16). Third, economics teachers don't consider humor as a respectable and professional alternative teaching method (Minchew \& Hopper, 2005). According to Ray (1991), those in the social sciences, especially economists, are generally "known more for squelching rather than quenching their human appetite for humor" (p. 227). This squelching behavior towards humor continues today despite the following reasons: (a) Students tend to rank humor as one of the most desirable teaching qualities (Weaver II \& Cotrell, 1987); (b) Rising pressures to make economics more attractive in order to increase student enrollment and maintain faculty teaching positions (Hansen, 1975); and finally (c) The growing respect for and use of humor as a viable and effective pedagogical technique in the classroom (Inman, 1991).

\section{BENEFITS OF HUMOR AS A TEACHING TECHNIQUE}

There are many benefits to students when humor is used in the classroom. These benefits can be social, psychological, communicative, and cognitive in nature.

\subsection{The Social Benefits of Humor}

Humor creates a welcoming teaching and learning environment by bridging the gap that exists between teachers and students (Robinson, 1977; Garner, 2005). Robinson (1977) writes that humor "breaks the ice, reduces fear of the unfamiliar, encourages a sense of trust and initiates a feeling of camaraderie and friendship" (p. 53). As a result the whole process and environment of teaching and learning becomes more humanized as students perceive that they are just as human as their teachers. Indeed teachers who take a lighthearted approach to teaching, and who aren't to laugh at themselves when they make mistakes, create a classroom atmosphere that is socially congenial to effective learning (Robinson, 1977; Berk, 2003).

\subsection{The Psychological Benefits of Humor}

The benefits of humor can be psychological. Humor can also be used to reduce the degree of tension and anxiety in the classroom (Berk, 2003; Powers, 2005). By reducing the level of stress and anxiety, humor can facilitate student learning by removing major impediments to learning such as the lack of self-confidence (Weaver II \& Cotrell, 1987).

\subsection{The Communication Benefits of Humor}

Humor plays a very important communication role by providing an appropriate channel through which serious or difficult information can be presented (Weaver II \& Cotrell, 1987). Through the avenue of humor, students are able to recall, retain, and relate better to the subject matter being communicated to them-especially when important points or concepts in lectures are embellished with content-relevant humor. Empirical studies conducted by Kaplan and Pascoe (1977) showed that test items based on humor improved the degree of recall significantly. 


\subsection{The Cognitive Benefits of Humor}

The use of humor as a teaching device can create a positive environment that facilitates student learning. Studies done to determine the relationship between humor and student learning show that the use of humor can increase and maintain student interest in a course (Lei et al., 2010). Humor is also seen as an important tool that can be used to motivate students as well as help them understand and retain course material (Weaver, Bryant, \& Zillman, 1988; Lei et al., 2010). Empirical work by Ziv (1988) also demonstrates that humor can unleash creativity and divergent thinking in students.

\section{GROUND RULES FOR TEACHING WITH HUMOR}

There are a number of precautions that must be adhered to if humor is to be used appropriately and effectively in the classroom. First, the use of humor in teaching should be approached not as an innate ability, but rather as a skill that can be learned and practiced just like most things in life (Cartwright, 1993). Second, in many ways humor is like a spice on the shelf in the kitchen cupboard-it must be used sparingly. Excessive use of humor in lectures and other course activities detracts from the subject matter being communicated and renders the whole teaching and learning experience a joke, no pun intended (Lei et al., 2010). Third, humor should be used in conjunction with other teaching tools and techniques if it is to remain effective (Cartwright, 1993). Fourth, humor should be relevant to the material being discussed. Humor for the sake of humor serves no constructive purpose, and the urge to do so must be resisted at all times (Hunsaker, 1988). This point is important if retention and recall of course material is to be encouraged. Weaver II et al. (1992) advises that humor and other just-for-the-fun-of-it activities should "be used in the interest of understanding and reflection - as energizers for content already in place" (p. 167). Finally, humor should be cautiously used in a manner that isn't offensive to students. Humor should never be used to humiliate students or hurt their feelings in any manner. Especially, humor shouldn't focus on such explosive topics as race, gender, or religion (Cartwright, 1993; Wanzer et al., 2006).

\section{TECHNIQUES OF INCORPORATING HUMOR IN THE INTRODUCTORY ECONOMICS COURSE}

As previously noted, the introductory economics course in general can potentially be very dry and boring to many new freshmen who may be taking the course as a requirement. Realizing this, I have worked strenuously to present economics in a way that is stimulating, interesting, and engaging to students. Discussed below are ideas and techniques for using humor to teach economics that I have developed or have borrowed from others.

\subsection{Don't Pretend to be a Comedian}

An instructor doesn't have to pretend to be a stand-up comedian in order to use humor. To use humor effectively in the classroom, he has to quickly come to grips with the fact that his primary goal of using humor is to facilitate student learning, and that humor is one of the many teaching devices in his teaching toolkit. Students are quite capable of making the distinction between a true comedian and a fake one. Trying too hard to mimic the performances of professional comedians risks diminishing the pedagogical value of humor altogether and of losing students' respect and regard for the instructor's integrity.

\subsection{Exploit the Power of Personal Stories and Anecdotes}

Everyone has a story to tell, and every instructor has a funny incident or two in their lives that can be used to convey the course materials to students. Stories are an effective way to captivate student attention and sustain their interest and motivation in the learning process. Indeed, funny stories and personal anecdotes based on the instructor's own experience as a student, and later as an economics teacher, can be a useful source of humor for teaching abstract economics concepts and models. These personal stories could entail the experiences that the instructor went through during his college days, and content-related incidences he has observed in his courses either from his students or from his own days of being a student (Weaver II \& Cotrell, 1987; Inman, 1991; Powers, 2005). 
Telling personal funny stories is perhaps one of my favorite ways of teaching with humor. For example, to illustrate the key characteristic of mutual interdependency under oligopoly, I talk about how my neighbors try to outdo one another when mowing their lawns, especially during early weekend mornings when I'm trying to catch up on some sleep. This example is a simple, true, and funny way of explaining strategic oligopoly behavior to students and it is a personal anecdote that students can relate to as well.

\subsection{Use Skits when Possible}

Sometimes acting out a concept or term leaves an indelible impression of the course material on the minds of students. Because of the humorous nature of the act, students are able to understand the concept, retain it, and recall it for later use. In my introductory as well as my principles of microeconomics courses for example, I illustrate, with the help of a skit, the role played by price elasticity of demand and supply in the determination of the tax incidence of an excise tax. To begin the skit, I invite two students of vastly different heights to participate. The taller student stands facing me, and the shorter student stands almost two feet directly behind the taller student. Both students stand facing me in single file. Before the skit begins, I whisper to the taller student to duck if they see a paper ball heading in their direction. The shorter student is not supposed to move. I roll up a sheet of paper into a ball, which is then hurled at the taller student. The paper ball may or may not hit the taller student or the shorter student. The skit ends once the paper ball hits either one of the student volunteers. In this skit the taller student represents the seller of the product and the intended target of the excise tax. The shorter student represents the buyer of the product and the unintended target of the excise tax. The paper ball represents the government's excise tax and the ducking action undertaken by the taller student is designed to demonstrate the seller's attempt to avoid paying excise taxes altogether. Who ends up paying the excise tax (i.e. the seller alone pays, the buyer alone pays, or both parties pay) can easily be illustrated using this simple, but funny skit.

\subsection{Develop a Collection of Humor Materials}

One effective way to begin using humor is to gather a file of content-relevant humorous materials. There is a mother lode of readily accessible sources of humorous material on economic jokes, cartoons, funny icons, stories, and quotations that can be incorporated into course lectures, tests, exams, quizzes, course syllabi, and handouts.

\subsubsection{Newspapers and Magazines}

Local, regional, as well as national newspapers, such as The New Yorker, Business Week, The Economist, and the Wall Street Journal often feature cartoons and other humorous economic quotes by leading politicians on different economic issues and policies.

\subsubsection{Textbooks and How-To Books on Humor}

A few textbook authors include humorous materials in their coverage of different concepts. For example, new introductory textbooks, especially those designed for non-majors or the general public, are punctuated with cartoon clips, quotations, and jokes. Notable among these are Yoram Bauman's The Cartoon Introduction to Economics: Volume One: Microeconomics and Volume Two: Macroeconomics (2010). Other books on humor and economics include Ronald Berk's Humor as an Instructional Defibrillator: Evidence-Based Techniques in Teaching and Assessment (2002) and Professors Are from Mars ${ }^{\circledR}$, Students Are from Snickers ${ }^{\circledR}:$ How to Write and Deliver Humor in the Classroom and in Professional Presentations (2003).

\subsubsection{The Internet}

Perhaps an even more important source of economic humor is the Internet. There is a significant number of humorous sources found on the Internet, more than in hard copy newspapers, magazines, and how-to books on humor. While a long laundry list of general-humor material is documented by Berk (2003), a more expansive list of economics-specific humor materials can be found at Dr. Dennis A. V. Dittrich's JokEc-Jokes about Economists and Economics. Website: economicscience.net/content/JokEc. This website consists of humorous economic poems, one line jokes, short stories, and top ten lists. 


\subsection{Use Extreme Examples as a Fun Technique}

Using extreme funny examples helps students to retain and recall course content. This is one technique I've used with great success. Students still remember my strange and unconventional examples years after graduating from my courses. For example the differences between the straight-line and the bowed-out production possibilities model is explained in terms of pregnancy and dieting, the Keynesian multiplier, as well as the differences between consumption and capital goods, are explained in terms of a black-eyed pea. Finally, the distinction between nominal and real GDP is explained in terms of two types of balloons - a deflated and an inflated balloon. Students find these examples weird but at the same time memorably humorous.

\subsection{The Instructor Must Make Every Effort to Know His Students}

To incorporate humor effectively in the introductory course, the instructor must make a concerted effort to know the background of his students. He must keep in mind that the extent that his humorous activities are received depends on how well he is able to adapt his humor to the lives of his students. There is usually quite a general age gap between instructors and their students, and therefore students may not agree with the instructor about what is or what is not humorous. For example, in order to find out what recreational activities students are involved in or the music they are listening to, I require each student to fill out a survey questionnaire, asking them to tell me a little bit about themselves: their school life, work life, and social life. Their responses are then incorporated into the various humor techniques I use throughout the course.

\section{SUMMARY AND CONCLUSION}

Those who teach the introductory economics course for non-majors can generate interest and excitement among their students if they dispensed with the traditional chalk-and-talk method of teaching. This traditional way of teaching has served to create and perpetuate the negative perception that economics is a dry, boring, and difficult subject. Unless this perception is reversed, the economic discipline risks losing students to other disciplines. Since the introductory economics course for many non-majors represents their first, and perhaps their only encounter with economics, every effort should be made by those who teach the course to make the course fun, interesting, relevant and appealing. One way this could be achieved is by experimenting with innovative teaching techniques that seek to remove the negative reputation that still plagues economics. One such technique is humor. Humor, appropriately incorporated into teaching, can deliver on the promise of turning students toward rather than away from economics.

\section{AUTHOR INFORMATION}

Dr. George H. Jones is an Associate Professor of Economics at the University of Wisconsin-Rock County in Janesville, Wisconsin. He obtained his B.S degree in Economics from the University of Wisconsin-Stevens Point, and M.S and Ph.D degrees from Southern Illinois University at Carbondale in Illinois. His recent research interests have focused on the pedagogical challenges of teaching economics to non-majors. He is the recipient of several teaching awards and honors including the prestigious University of Wisconsin System Underkofler Excellence in Teaching Award. E-mail: george.jones@uwc.edu

\section{REFERENCES}

1. Armento, B. J. (1987). Ideas for teaching economics derived from learning theory. Theory Into Practice, 26(3), 176-182.

2. Bach, G. L., \& Kelley, A. C. (1984). Improving the teaching of economics: Achievements and aspirations. The American Economic Review, 74(2), 12-18.

3. Bauman, Y. (2010). The cartoon introduction to economics: Volume one and two: Microeconomics (Vol. 1) and Macroeconomics (Vol. 2). Macmillan.

4. Becker, W. E., \& Watts, M. (1996). Chalk and talk: A national survey on teaching undergraduate economics. The American Economic Review, 86(2), 448-453.

5. Becker, W. E., \& Watts, M. (2001). Teaching economics at the start of the $21^{\text {st }}$ century: Still chalk-and-talk. The American Economic Review, 91(2), 446-451. 
6. Berk, R. A. (2002). Humor as an instructional defibrillator: Evidence-based techniques in teaching and assessment. Stylus Publishing, LLC.

7. Berk, R. A. (2003). Professors are from Mars, Students are from Snickers: How to write and deliver humor in the classroom and in professional presentations. Stylus Publishing, LLC.

8. Bryant, J., Comisky, P., \& Zillmann, D. (1979). Teachers' humor in the college classroom. Communication Education, 28(2), 110-118.

9. Cartwright, L. J. (1993). Practical techniques for incorporating humor in the classroom. The Teaching Professor, August/September, 7-8.

10. Colander, D. (2000). Telling better stories in introductory macro. The American Economic Review, 90(2), 76-80.

11. Deiter, R. (2000). The use of humor as a teaching tool in the classroom. NACTA Journal, 44(2), $20-27$.

12. Garner, R. (2005). Humor, analogy, and metaphor: HAM it up in teaching. Radical Pedagogy, 6(2), 1.

13. Hansen, L. W. (1975). New approaches to teaching the principles courses. The American Economic Review, 65(2), 434-437.

14. Hunsaker, J. S. (1988). It's no joke using humor in the classroom. The Clearing House, 61(6), $285-286$.

15. Inman, D. (1991). Humor in the classroom as a teaching strategy. Adult Learning, 2(7), 29-29.

16. Kaplan, R. M., \& Pascoe, G. C. (1977). Humorous lecture and humorous examples: Some effects upon comprehension and retention. Journal of Educational Psychology, 69(1), 61-65.

17. Lawson, R., Hull, J., \& Mateer, G. D. (2008). From Abba to Zeppelin, Led: Using music to teach economics. Journal of Economic Education, 39(1), 107-107.

18. Leet, D., \& Houser, S. (2003). Economics goes to Hollywood: Using classic films to create an undergraduate economics course. Journal of Economic Education, 34(1), 326-332.

19. Lei, S. A., Cohen, J. L., \& Russler, K. M. (2010). Humor on learning in the college classroom: Evaluating benefits and drawbacks from instructors' perspectives. Journal of Instructional Psychology, 37(4), 326331.

20. Minchew, S. S., \& Hopper, P. F. (2008). Techniques for using humor and fun in the language arts classroom. The Clearing House: A Journal of Educational Strategies, Issues and Ideas, 81(5), 232-236.

21. Moran, Jeffrey, B. (1994). Humor in science education. Science Teacher, 61(5), 39-40.

22. Powell, J. P., \& Andresen, L. W. (1985). Humor and teaching in higher education. Studies in Higher Education, 10(1), 79-90.

23. Powers, T. (2005). Engaging students with humor. Association for Psychological Science Observer, $18,12$.

24. Ray, M. A. (1991). The lighter side of the dismal science: The humor of economics. The Social Science Journal, 28(2), 227.

25. Robinson, V. M. (1977). Humor and the health professions. Thorofare, NJ: CB Slack.

26. Robinson, V. M. (1991). Humor and the health professions. Thorofare, NJ: CB Slack.

27. Ruder, P. (2006). Teaching economics with short stories. Available at SSRN 926220.

28. Ulloth, J. K. (2003). A qualitative view of humor in nursing classrooms. Journal of Nursing Education, 43(3), 125-130.

29. Vo, H. X., \& Morris, R. L. (2006). Debates as a tool in teaching economics: Rationale, technique and some evidence. Journal of Education for Business, 81(6), 315-320.

30. Wanzer, M. B., Frymier, A. B., Wojtaszcyyk, A., \& Smith, T. (2006). Appropriate and inappropriate uses of humor by teachers. Communication Education, 55(2), 178-196.

31. Watts, M., \& Becker, W. W. (2008). A little more than chalk and talk: Results from a third national survey of teaching methods in undergraduate economics courses. Journal of Economic Education, 39(3), 273-286.

32. Weaver, J., Bryant, J., \& Zillman, D. (1988). Effects of humorous distortions on children's learning from educational television: Further evidence. Communication Education, 37(3), 181-187.

33. Weaver II, R., \& Cotrell, H. (1987). Ten specific techniques for developing humor in the classroom. Education, 108(2), 167-179.

34. Weaver II, R. L., Kosan, J., \& Cotrell, H. W. (1992). Mental aerobics. Just for the fun of it. The Clearing House, 65(3), 167-171.

35. Ziv, A. (1988). Teaching and learning with humor: Experiment and replication. The Journal of Experimental Education, 5-15. 